\title{
Enabling Teacher Librarian Leadership for Technology Integration
}

\author{
Melissa P. Johnston \\ Assistant Professor \\ University of Alabama \\ School of Library \& Information Studies \\ Tuscaloosa, AL USA \\ mpjohnston@slis.ua.edu
}

\begin{abstract}
The highly technological environment of $21^{\text {st }}$ century schools has significantly redefined the role of the teacher librarian by presenting the opportunity to assume leadership roles through technology integration. The teacher librarian must evolve as a leader in order to address the needs of today's learners and ensure that they are equipped with the knowledge and skills they need to use technology as an important tool for learning. This research, based on distributed leadership theory investigates practices of teacher librarians in order to identify what is enabling some to thrive as technology integration leaders and what is hindering others. This paper presents the findings from the replication research identifying what is enabling some teacher librarians to thrive as technology integration leaders and serve as a foundation on which to build researchbased strategies to support practicing teacher librarians in understanding how to enact this vital role and on how to better prepare future teacher librarians for a leadership role in the integration of technology.
\end{abstract}

Keywords: teacher librarianship, leadership, technology integration

\section{Introduction}

The ubiquitous presence of technology and digital resources has resulted in major changes in education in the 21 st century, leaving schools searching for ways to deal with and integrate technology for learning. This presents an important opportunity for teacher librarians as they themselves seek to establish their place in these efforts and maintain relevancy in the digital age. Teacher librarians are in a unique position to make meaningful contributions to the integration of technology for teaching and learning due to their knowledge of pedagogical principles and curriculum paired with their technology and information expertise (Johnston, 2012). As technology and digital resources have evolved to an essential component of teaching and learning, teacher librarians have been afforded the opportunity to be responsible for the management and integration of technology as many U.S. schools are utilizing the expertise of the teacher librarian as a key element in the transition to digital learning to aid in the effective integration of technology to improve student outcomes (Wolf, Jones, \& Gilbert, 2014). 
This research is a replication of previous research conducted in 2011 that examined the enablers and barriers teacher librarians experience enacting a leadership role in technology integration. The original research focused on a purposive sample of those teacher librarians in the United States who have obtained National Board certification. The present research was conducted with a random nation-wide sample of teacher librarians across the United States.

\section{Research Purpose}

As technology permeates teaching and learning, teacher librarians are continually directed to assume a leadership role in integrating technology in schools from professional standards and guidelines, as well as from theorists and researchers in this area (e.g., Everhart \& Dresang, 2006; Everhart, Mardis, \& Johnston, 2011; Hanson-Baldauf \& Hughes-Hassell, 2009; Shannon, 2002), yet there is limited research and direction on how to enact this role in practice. The ambiguity surrounding the technology integration leadership role has led to teacher librarians who are uncertain how to and ill-prepared to enact this vital role. The specific purpose of this research was to identify what is enabling some teacher librarians to thrive in the role of technology integration leader, as well as the barriers they face, to inform practice and further the understanding needed to enact this role successfully.

The goal of this research was to serve as a foundation on which to build research-based strategies to support practicing teacher librarians who seek to overcome barriers, and to distinguish those factors that enable this vital role to be achieved in practice and to inform teacher librarian preparation programs in preparing future teacher librarians for a leadership role in the integration of technology. Additionally, this research is a replication of previous research, but with a larger random sample of teacher librarians from across the United States and serves not only to lend validity to the findings, but also strengthen the application of the theoretical framework and conceptual framework to teacher librarian research. This report of the findings will focus on the enabling factors from a nationwide survey of teacher librarians from across the United States.

\section{Defining Technology Integration}

In the world of education there is much terminology with multiple definitions, technology integration being among these. For this research technology integration is defined as Curriculum integration with the use of technology involves the infusion of technology as a tool to enhance the learning in a content area or multidisciplinary setting. Technology enables students to learn in ways not previously possible. Effective integration of technology is achieved when students are able to select technology tools to help them obtain information in a timely manner, analyze and synthesize the information, and present it professionally. The technology should become an integral part of how the classroom functions - as accessible as all other classroom tools. The focus in each lesson or unit is the curriculum outcome, not the technology. (ISTE, 2000 , p. 6)

The key to technology integration in education is that technology is seamlessly blended to enhance the learning experience and develop learners' thinking skills, not as an add-on or afterthought (Hew \& Brush, 2007). "Leveraging technology can help...improve learning and assessment, technology can help... build the capacity of educators by enabling a shift to a model of connected teaching" (Office of Educational Technology, 2010, p. 39). The National Educational Technology Plan set out three categories that define technology integration by 
teachers: "powerful use of innovative digital teaching objects; curriculum planning and assessment to ensure consistency and differentiation; a new digital and teaching learning environment." Access to technology and digital resources for teaching and learning has become paramount, with the school library and the teacher librarian becoming key components in providing access to these resources, yet teacher librarians also have expertise to offer in regards to effectively integrating technology (Everhart et al., 2012; Johnston, 2011; Mardis, ElBasri, Norton, \& Newsum, 2012).

\section{Why Technology Integration?}

Integration of technology in schools has changed the world of education and also the way teachers instruct and that students learn. Technology provides ways to enhance instruction, personalize it, make it relevant for students, and therefore engage them in the learning process. Progress is also being made in the research that reinforces the benefits of effectively integrating technology and the link to student achievement, which has led to an increasing number of educators realizing the potential that technology has in their efforts to improve student achievement (e.g. Darling-Hammond, Zielezinski, Goldman, 2014; Project Tomorrow, 2014; Duffey \& Fox, 2012). There are also many federal and state policies that encourage greater use of instructional technology, coining the term "digital learning" (e.g. Alliance for Excellent Education, 2011; Office of Educational Technology, 2010; U.S. Department of Education, 2013). The Alliance for Excellent Education defines digital learning as "any instructional practice that is effectively using technology to strengthen the student learning experience." Digital learning encompasses a broad array of tools and practices, including online courses, applications of technology in the classroom, computer-based assessment, and adaptive software for students with special needs (Alliance for Excellent Education, 2012).

\section{Why the Teacher Librarian?}

Since Information Power was released in 1998 (ALA), teacher librarians in the United States have been tasked as the person responsible for technologies in the school. In 2009, when Empowering Learners: Guidelines for School Library Media Programs (AASL, 2009) was released, the belief that teacher librarians should act as leaders within their school communities to ensure that learners are equipped with the skills and knowledge they need to succeed and participate in the technological society of the 21 st century was emphasized. Teacher librarians are charged, "to play a leading role in weaving such skills throughout the curriculum so that all members of the school community are effective users of ideas and information" (AASL, 2009, p. 46). It is this "weaving" or the integration of technology into the curricular areas where teacher librarians, based on their knowledge of pedagogical principles and school curriculum, technology expertise, and collaborative experience, can serve as leaders and valuable assets to their schools (Johnston, 2012).

Increasingly learning resources and tools are digital, and while the number of teachers using these resources in their classroom is increasing, there are still issues with effectively integrating and appropriately utilizing them to present new opportunities for student learning (Common Sense Media, 2013; digedu, 2014; Mardis et al., 2012; Project Tomorrow 2012). Teachers are still struggling in locating digital resources, with a majority of teachers agreeing that it is difficult to find the digital resources they need and research shows that educators are regularly frustrated when seeking digital resources to support the needs of a variety of students (Common Sense Media, 2013; Mardis et al., 2012). Further, educators' confidence 
in locating and selecting digital resources has been shown to influence their future use of these resources for instruction, yet teachers lack adequate information skills to locate and manage educational resources and continue to express being overwhelmed by the amount of digital resources when searching for resources to support their instruction (Albertson \& Johnston, 2015; Common Sense Media, 2013; Diekema \& Olsen, 2012; Duke \& Ward, 2009; Mardis et al., 2012). It is this lack of information skills and frustration that continue to lead to the underutilization of digital resources by educators even though they are aware of the importance and usefulness demonstrating that teachers are in need of professional development instruction for locating and identifying digital content, to enhance student learning (Albertson \& Johnston, 2015; Common Sense Media, 2013; Diekema \& Olsen, 2012; digedu, 2014; Mardis, 2009; Project Tomorrow, 2014).

The research supports the assertion that teacher librarians must embrace their leadership role in technology integration, identifying two roles of the teacher librarian that impact student achievement: leader and technology facilitator (Scholastic, 2008). Classroom teachers need assistance in harnessing the new technology and digital tools for both teaching and learning and teacher librarians can lead the efforts to integrate digital resources and technologies effectively into all disciplines across the curriculum and at every grade level (Albertson \& Johnston, 2015; Common Sense Media, 2013; Diekema \& Olsen, 2012; Duke \& Ward, 2009; Johnston, 2012; Mardis et al., 2012). Teacher librarians can lead through modeling and partnering with teachers to offer expertise on the integration of emergent technology and digital resources, through keeping teachers abreast on new technologies, facilitate teachers' efforts to utilize technology through ongoing professional development opportunities that help them learn how to use new technologies, the instructional strategies needed to integrate technology into their teaching, including practical applications (AASL, 2009; Branch-Mueller \& de Groot, 2011; Ertmer, 2005; Everhart et al., 2010; Johnston, 2011).

Students also need support in digital learning, with the AASL Standards asserting that with the changing information landscape of the 21 st century that includes interactive technologies and a participatory culture, teacher librarians must evolve as leaders to address the needs of this new generation of learners. As educators it is the responsibility of teacher librarians to prepare students for their future and to "develop information skills that will enable them to use technology as an important tool for learning, both now and in the future" (AASL, 2007, p. 2). Students need to be taught the skills they need to create, invent, design, and expand their world by actively participating in the digital culture (Todd, 2008). Addressing these needs requires a shift in thought about instructional practice and provides an opportunity for teacher librarians to lead by applying their knowledge of learners, curriculum, and technology to enact changes in the way teachers utilize technology to connect to their students to create engaging and relevant learning experiences for students (AASL, 2009). These $21^{\text {st }}$ century learners and the new literacies that they require present the opportunity for teacher librarians to assume leadership roles within their schools through modeling and teaching integrating technology (Hanson-Baldauf \& Hughes-Hassell, 2009; Johnston, 2011).

\section{Theoretical Framework: Distributed Leadership Theory}

This research assumes that teacher librarians operate as teacher leaders within a school and the leadership practices of teacher librarians are essentially those of teacher leaders.

Teacher leaders are those teachers that assume informal and formal leadership responsibilities outside the classroom, create a participatory environment where all learn 
from each other, and engage with others in working together for student learning (Katzenmeyer \& Moller 2009; Spillane 2006). Therefore this research is based on the educational leadership theory of distributed leadership, which asserts that leadership is about more than just people in formal leadership positions and attempts to acknowledge all contributors, formal or informal, who participate in leadership practice (Spillane 2006). The most contemporary interpretation of distributed-leadership theory from Spillane defined leadership as -the activities tied to the core work of the organization that are designated by organizational members to influence the motivation, knowledge, affect, or practices of other organizational members as intended to influence their motivation" (2006, p. 11) and leadership practice as - the activities engaged in by leaders, in interaction with others in particular context around specific tasks" (2006, p. 5). Spillane has asserted that in a distributed approach, it is necessary to start by examining leadership practices and then to explore interactions among leaders, followers, and their situation. A fundamental proposition of distributed leadership is that "the situation is not simply a context within which school leaders practice; it is a defining element of practice" (Spillane, 2006, p. 22). Aspects of the situation define leadership practice, and, therefore, it is necessary to understand how these aspects enable and constrain leadership practice. It is this proposition, in Spillane's interpretation of distributed-leadership theory, that formed the theoretical basis, and presented a means for exploring and analyzing the leadership activities, actions, and role of teacher librarians.

\section{Method}

The collection of new research is not always a necessary step in the research process; it is sometimes possible to examine a new research question using previously collected data, or secondary analysis. Original survey research rarely uses all of the data collected and this unused data can provide answers or different perspectives to other questions or issues (Clark \& Maynard, 1998), therefore the researcher chose to utilize unused archived survey data that addresses the enablers and barriers teacher librarians perceive when enacting technology integration leadership practices.

\section{Data Collection}

This research utilizes the data obtained from the two open-ended questions at the end of the School Library Media Specialist and Technology Integration Survey (PALM, 2009), which asked respondents about enablers and barriers that facilitate or constrain their technology integration leadership involvement. This was the same instrumentation utilized in the previous research with the sample only consisting of National Board Certified teacher librarians (Everhart et al., 2012).

Technology integration leadership practices, for the purposes of this research, are identified as those found in the School Library Media Specialist Technology Integration Survey (PALM, 2009) (Appendix A). The first section of the survey consisted of 30 demographic questions covering areas such as staffing levels, education and experience of the teacher librarians, as well as questions relating to the technology available and Internet accessibility in the school where they worked. The second section, and the main focus of the survey, was 60 statements related to technology integration activities with response choices for statements that reflected respondents' degree of leadership regarding the particular integration activity: $0=$ Not my job; 1 =Rarely involved; $2=$ Partially involved; $3=$ Substantially involved; $4=$ Fully involved. Each of these response choices was fully explained in the context of the survey 
instrument. Finally, there were open-ended questions that asked respondents to discuss barriers, enablers, and other factors that influenced their leadership practices. These questions ask respondents to "Think back about the activities in the preceding statements, specifically those in which you are fully involved. What enables you to be involved at that level?" and "Again, think about those activities addressed earlier. Are there any activities in which you'd like to be more involved than you are right now? If so, please tell us about the barriers that hinder your involvement" (PALM, 2009). This research focuses on the two openended questions as they allowed respondents to provide a personal answers in their own words to questions; which yield useful information, especially when researchers need to explore issues that do not have a finite or predetermined set of responses (Babbie, 2013; Dillman, Smyth, \& Christian, 2009) as is the case in this research.

\section{Participants}

The participants in this research are the same as those documented in the primary research teacher librarians practicing in various schools across the United States at the elementary, middle, and high school levels. The 1183 usable survey responses from the primary study of teacher librarians practicing in various schools across the United States at the elementary, middle, and high school levels is the same sample utilized by this secondary research. This research is based on those respondents who answered the open-ended question addressing the variable of interest, enablers to the enactment of the leadership role in technology integration. Upon obtaining the original data it was found that $976(82.5 \%)$ participants that answered the enabler question.

\section{Procedure}

Secondary analysis is a systematic method with procedural and evaluative steps to be followed, just as there are in collecting and evaluating primary data. The advantage is that the data already exist in some form and can be evaluated for appropriateness and quality in advance of actual use (Stewart \& Kamins, 1993); however, it is important to identify and evaluate data in a "stepwise fashion." The researcher utilized Stewart and Kamins' (1993) six step process for evaluating a dataset: (a) what was the purpose of this study; (b) who was responsible for collecting the information; (c) what information was actually collected; (d) when was the information collected; (e) how was the information obtained; and (f) how consistent is the information obtained from one source with information available from other sources. In answering these questions the researcher utilized documentation of the primary study, information from the original study found in publication, and consulted the investigators from the primary study. In the case of this replicated research the data from the School Library Media Specialist and Technology Integration Survey (PALM, 2009), was once again evaluated to ensure congruency, appropriateness, and quality of the primary study and the resulting dataset.

\section{Data Analysis}

This research employed content analysis for "systematic, objective, quantitative analysis of message characteristics" (Neuendorf, 2002, p. 1). In the case of this research, the messages are the responses to the two open-ended survey questions. Content analysis allowed for coding and categorizing the text in a way that relationships could be identified. The goal of this content analysis was to identify the enablers perceived by respondents, categorize them, and then determine frequency. 
In order to extract the specified enablers and barriers from the text of the open-ended questions, the researcher performed content analysis. The researcher has 12 years of experience as a teacher librarian; this background of practice and commonality of experience assisted the researcher in performing the content analysis through reading each response to determine manifest and latent content enablers and barriers. The participant responses were read and analyzed to extract individual descriptors of enablers and barriers. In most cases, participants listed more than one enabler in their responses. Once enablers were identified, they were spilt into separate fields in the spreadsheet, but each remained connected to their individual case number. This resulted in 2222 enablers to be considered for analysis. The content analysis and data coding resulted in the identification of the perceived enablers and barriers for teacher librarians in enacting a leadership role in technology integration.

Following Neuendorf's (2002) procedure for content analysis, the researcher utilized an a priori coding scheme of exhaustive and mutually exclusive categories taken from the conceptual framework. In the previous research, the conceptual framework The Four Domains of Supports and Barriers to Teacher Leadership (Zinn, 1997), taken from teacher leadership research, was utilized to categorize the enablers and barriers. A result of that research was an adapted version of the framework for teacher librarians, Johnston's Domains of Enablers and Barriers to School Librarian Technology and Leadership (Johnston, 2011). This newly created framework was utilized in this replicated research and the enablers were coded and categorized based on the Johnston's Domains framework (Appendix B) which are: Domain One: People and Interpersonal Relationships, Domain Two: Institutional Structures, Domain Three: Personal Considerations and Commitments, and Domain Four: Intellectual and Psycho-social Characteristics. This framework explicitly lists descriptor indicators within each category of specific enablers and barriers that reside in each domain. The data was coded by the most finite enabler descriptor and by broader domain as well.

\section{Results}

The result of the content analysis was the identification of the perceived enablers for teacher librarians in enacting a leadership role in technology integration, as well as frequency distribution tables. Frequency or univariate tables represent the simplest method for analyzing categorical data and are often used as a procedure to review how different categories of values are distributed in the sample (Vaughn, 2001). Table 1 displays the list of enablers, in descending frequency in which participants mentioned the enabler as facilitating involvement in technology integration leadership.

\begin{tabular}{lccccc}
\hline Enablers & Rep. $\boldsymbol{f}$ & Rep. \% & $\begin{array}{c}\text { Initial } \\
\boldsymbol{f}\end{array}$ & $\begin{array}{c}\text { Initial } \\
\%\end{array}$ & $\begin{array}{c}\% \\
\text { Difference }\end{array}$ \\
\hline $\begin{array}{l}\text { Supportive principal } \\
\begin{array}{l}\text { Opportunities for a leadership role and } \\
\text { responsibilities }\end{array}\end{array}$ & 230 & 10.3 & 70 & 9.67 & 0.63 \\
$\begin{array}{l}\text { Commitment to continual professional } \\
\text { growth }\end{array}$ & 171 & 7.69 & 41 & 5.66 & 2.03 \\
$\begin{array}{l}\text { Desire to make a difference for } \\
\text { students and teachers }\end{array}$ & 157 & 7.06 & 69 & 9.53 & -2.47 \\
$\begin{array}{l}\text { Collaborative teachers } \\
\text { n }\end{array}$ & 132 & 5.94 & 33 & 4.56 & 1.38 \\
\hline
\end{tabular}




\begin{tabular}{|c|c|c|c|c|c|}
\hline Enablers & Rep. $f$ & Rep. \% & $\underset{f}{\text { Initial }}$ & $\begin{array}{c}\text { Initial } \\
\%\end{array}$ & $\begin{array}{c}\% \\
\text { Difference }\end{array}$ \\
\hline Sense of obligation to get involved & 131 & 5.89 & 48 & 6.63 & -0.74 \\
\hline Personal interest in technology & 92 & 4.1 & 19 & 2.62 & 1.48 \\
\hline Personal belief and values & 90 & 4.0 & 22 & 3.04 & 0.96 \\
\hline Professional organizations & 115 & 5.17 & 33 & 4.56 & 0.61 \\
\hline $\begin{array}{l}\text { Professional development } \\
\text { opportunities }\end{array}$ & 74 & 3.3 & 60 & 8.29 & -4.99 \\
\hline Technology resources & 72 & 3.2 & 15 & 2.07 & 1.13 \\
\hline Respected and valued by staff & 68 & 3.1 & 15 & 2.07 & 1.03 \\
\hline Flexible schedule & 64 & 2.88 & 12 & 1.66 & 1.22 \\
\hline Expertise & 63 & 2.8 & 36 & 4.97 & -2.17 \\
\hline District level support & 61 & 2.7 & 17 & 2.35 & 0.35 \\
\hline Time & 57 & 2.56 & 11 & 1.52 & 1.04 \\
\hline Supportive teachers & 53 & 2.38 & 12 & 1.66 & 0.72 \\
\hline Professional responsibility & 52 & 2.3 & 18 & 2.49 & -0.19 \\
\hline Dual role as instructional technologist & 48 & 2.16 & 16 & 2.21 & -0.05 \\
\hline Collaborative instructional technologist & 46 & 2.1 & 7 & 0.97 & 1.13 \\
\hline Education & 35 & 1.57 & 16 & 2.21 & -0.64 \\
\hline Personal time & 35 & 1.57 & 2 & 0.28 & 1.29 \\
\hline Experience & 34 & 1.5 & 14 & 1.93 & -0.43 \\
\hline Funding & 32 & 1.4 & 15 & 2.07 & -0.67 \\
\hline Full-time clerk & 30 & 1.3 & 10 & 1.38 & -0.08 \\
\hline Supportive district personnel & 27 & 1.2 & 17 & 2.35 & -1.15 \\
\hline Full-time tech support & 14 & 0.63 & 5 & 0.69 & -0.06 \\
\hline Small school population & 9 & 0.40 & NA & NA & \\
\hline Supportive school climate & 8 & 0.36 & 5 & 0.69 & -0.33 \\
\hline Volunteers & 6 & 0.27 & 5 & 0.69 & -0.42 \\
\hline Curriculum & 6 & 0.27 & NA & NA & \\
\hline Staffing & 6 & 0.27 & NA & NA & \\
\hline Personal finances & 5 & 0.22 & 1 & 0.14 & 0.08 \\
\hline Standards & 5 & 0.22 & NA & NA & \\
\hline Family support & 3 & 0.13 & 1 & 0.14 & -0.01 \\
\hline Students & 2 & 0.09 & NA & NA & \\
\hline
\end{tabular}

Table 1: Frequency Distribution of Leadership Enactment Enablers

Note. The replication \% (Rep. \%) symbolizes the percentage that the specific enabler was found in relation to all the total identified enablers $(n=2222)$. The initial \% symbolizes the percentage that the specific enabler was found in relation to all the total identified enablers $(n=724)$. 
The researcher calculated frequency distribution tables for the enablers in each of the four domains (Table 2), finding: Domain One: People and Interpersonal Relationships $(n=673)$, Domain Two: Institutional Structures $(n=681)$, Domain Three: Personal Considerations and Commitments $(n=43)$, and Domain Four: Intellectual and Psycho-social Characteristics $(n=825)$. This framework explicitly lists descriptor indicators within each category of specific enablers and barriers that reside in each domain.

\begin{tabular}{|c|c|c|c|c|c|}
\hline Domain & Rep. $f$ & Rep. \% & Initial f & $\begin{array}{c}\text { Initial } \\
\%\end{array}$ & $\begin{array}{c}\% \\
\text { Difference }\end{array}$ \\
\hline $\begin{array}{l}\text { Domain 1: People \& Interpersonal } \\
\text { Relationships }\end{array}$ & 673 & 30.28 & 188 & 25.97 & 4.31 \\
\hline Domain 2: Institutional Structure & 681 & 30.64 & 243 & 33.56 & -2.92 \\
\hline $\begin{array}{l}\text { Domain 3: Personal } \\
\text { Considerations \& Commitments }\end{array}$ & 43 & 0.02 & 4 & 0.55 & -0.035 \\
\hline $\begin{array}{l}\text { Domain 4: Intellectual \& Psycho- } \\
\text { social Characteristics }\end{array}$ & 825 & 37.12 & 289 & 39.92 & -2.8 \\
\hline
\end{tabular}

Table 2. Frequency of Leadership Enactment Enablers Categorized by Johnston's Domains of Enablers and Barriers to School Librarian Technology and Leadership

Note. The replication \% (Rep. \%) symbolizes the percentage of enablers in the Domain in relation to all the total identified enablers $(n=2222)$. The initial \% symbolizes the percentage of enablers in the Domain in relation to all the total identified enablers in the initial study $(n=724)$.

\section{Findings and Discussion}

This report of the findings focuses on the identification of the factors that enable teacher librarians to be fully involved in technology integration leadership practices. Overall it was found that the random sample of U.S. teacher librarians mirrored the results of those teacher librarians in the U.S. who have achieved National Board certification. The conclusions about those most frequently identified enablers and the similarities and differences in the two populations will be discussed.

\section{Relationships}

The "success or failure of teacher leadership depends in large part on the effectiveness or personal support systems, mutual respect, and interdependency" (Zinn, 1997, p. 17). As in the initial research, the relationships identified as frequently occurring factors in teacher librarians' technology integration leadership enactment include: the principal, the district administrator, teachers, other teacher librarians, and instructional technologists. As in the initial study, the most frequently cited enabler in teacher librarians enacting a leadership role in technology integration is a supportive principal. Respondents comment on encouragement they received from their principal in assuming a leadership role and responsibilities, such as "I have a principal who encourages my participation. I am asked to get involved in technology related committees and groups." Others describe respectful relationships where leadership was shared and their opinion was valued, with responses such as "I work for a principal who has confidence in my ability to research, apply and teach new technologies" and "support from my principal who values my skills and expertise" as enablers to technology leadership enactment. The quality of a principal's relationship with teachers is correlated with teachers' 
willingness to participate in teacher leadership: the more open, supportive, and facilitative a principal is with teachers, the more willing they are to take on a leadership role (York-Barr \& Duke, 2004).

Administrators other than the school principal serve as enablers for teacher librarians in enacting technology integration leadership. Slightly more participants spoke of a district school library coordinator or supervisor who facilitated their efforts in technology integration leadership. One comment was that "we have a media director who oversees the district's media program and helps each media specialist with education and technology initiatives" This facilitating relationship with district administrators is not prevalently mentioned in the teacher leadership literature and only limited research exists in the teacher librarian literature (DiScala, Moses, \& Weeks, 2015; Hughes-Hassel \& Hanson-Baldauf, 2008; Johnston, 2011) that examines this connection. The association of the district library supervisor as an enabler is a relationship that has emerged from this research and appears to be unique to teacher librarians.

Participants in both studies highly noted collegial relationships with teachers serving as enablers that facilitate teacher librarians' enactment of a leadership role in technology integration. Respondents spoke not only of teachers supporting them in their efforts through serving as "critical friends," but also through respecting and valuing their contributions to technology integration efforts and in their willingness to collaborate with them. For example, one respondent shared that "collaboration with classroom teachers provides me opportunities to instruct students and teachers" was what enabled them to function as technology integration leaders. Cultivating accepting and trustful relationships with teachers is vital for enacting leadership. In the initial study participants spoke of the importance of professional organizations as enabling their leadership, in this replication that same finding was present with respondents increasingly naming local, state, and national professional organizations that serve as enablers. Professional organizations provide support for teacher librarians through relationships with other school librarians, but this research finds that professional growth opportunities from professional organization activities such as conferences and publications serve as enablers as well. One respondent expresses that "professional organizations keep my knowledge fresh and me involved." These findings reveal the importance of professional organizations as providing a network of fellow teacher librarians to learn from and share with. Finally, a relationship that emerged from the initial research and was also prevalent in this replication was the collaborative relationship with their building level instructional technology specialist. Respondents noted "having a great professional and personal relationship with the tech specialist" and of being viewed "as a full partner" by the instructional technology specialist when it comes to technology integration. The emerging relationship between the teacher librarian and technology specialists is one that is of great concern as schools search for ways to deal with the increased demands of technology for teaching and learning (Johnston, 2015).

\section{Leadership and Professional Development Opportunities}

Opportunities for an authentic leadership role and responsibilities were mentioned very frequently as enabler facilitating involvement in technology integration leadership in both studies. It must also be noted that a school principal's influence in enabling leadership enactment is overarching in that the principal can serve to encourage and promote teacher leadership opportunities with formal appointments such as creating teams to address certain 
tasks or responsibilities as a substitute for administrative leadership, suggesting a teacher conduct a professional development session in an area of expertise or creating a situation for spontaneous leadership to emerge (Spillane, 2006). Both studies found that leadership opportunities, such as serving on leadership, technology, and curriculum committees at the school and the district level served as natural enablers for involvement in technology integration leadership. Teacher leaders require opportunities to be involved in school decision-making and to be involved in the professional development of others (Katzenmeyer \& Moller, 2009; Spillane, 2006). When educators are part of decision-making, they feel that their expertise is valued and they increase their commitment and participation in the school (Barth, 2001). Also respondents describe serving in a leadership role as providers of staff development for their faculty. Teacher librarians have the potential to serve as leaders through "forg[ing] partnerships" with teachers and sharing their expertise with the teaching staff by using collaborative activities and by designing and teaching staff development workshops (Zmuda \& Harada, 2008, p. 39). Opportunities for leadership are vital in providing teacher librarians with the experience, confidence, and skills necessary for leadership involvement. Participants in both studies mentioned opportunities for professional development frequently, but the professional development was more related to technology, rather than leadership skills. The teacher librarian respondents in both studies perceive professional development activities and opportunities that were devoted to technologies and learning to be essential for developing "expertise" in technology and technology integration in order to lead. This research reveals the important connection to expertise; in order to assume a leadership role in technology integration it is important to have the technology expertise necessary, including the knowledge and skills to integrate technology into instruction. Yet, the teacher leadership literature asserts that instructional expertise alone is insufficient to allow teachers to function as instructional leaders and requires knowledge and skills related to leadership in addition to the instructional expertise (Barth, 2001; Katzenmeyer \& Moller, 2009). Therefore the same could be assumed for teacher librarian leaders, signifying a needed change in the professional development needed for teacher librarians.

\section{Self-Initiative}

Six of the top ten most frequent enablers identified in both studies reside in Zinn's framework as intellectual and psycho-social characteristics including a commitment to continual professional growth, a desire to make a difference for students and teachers, sense of obligation to get involved, personal interest in technology, and personal beliefs and values. In this domain the teacher librarian, herself serves as an enabler to leadership enactment; these enablers represent the personal characteristics and beliefs that can serve to facilitate one to assume leadership responsibilities (Zinn, 1997). Teacher librarians in both studies illustrate these same beliefs. The perception that one can make a difference in the lives of student and teachers is prominently identified as the third third most frequently occurring enabler facilitating teacher librarians' involvement in technology integration leadership practices demonstrating the commitment of teacher librarians to ensuring that students are equipped with the skills and knowledge they need for success. Respondents often noted a responsibility to advocate on behalf of students to ensure access and equity, commenting on the importance of ensuring that students are equipped for their future, can use technology in their learning, and making sure that teachers know how to integrate technology to benefit the students. This intrinsic reward of improving learning outcomes for students is rewarding work 
for teacher librarians and serves as an enabler for technology integration leadership enactment.

Teacher librarians in both studies also commented on being enabled by personal connections to their tasks through their personal interest in technology, personal values and beliefs that demand excellence, and a professional responsibility. These findings illustrate the parallels between teacher leaders and teacher librarians in taking ownership of, and responsibility for, maximizing student learning. This is consistent with the finding of HansonBaldauf and Hughes-Hassell (2009) that teacher librarians agree that integrating technology into their instruction is an important aspect of their job. Strong personal beliefs can serve to motivate teachers to assume leadership responsibilities through belief in strong work ethics, a need to maximize talents and expertise, and commitment to excellence (Zinn, 1997). Recent scholars have recognized that successful leaders have a clear awareness of their values and beliefs and these leaders work with integrity allowing values and beliefs dictate their decision-making. Many teacher leaders prefer leading to following when the issues have personal importance or there is a sense of connection with the task (Sergiovanni as cited in Robertson, 2008).

A personal sense of obligation to get involved in technology integration leadership activities is found to facilitate involvement in technology integration leadership activities. Teacher librarians in both studies reflect a willingness with comments such as feeling a need to get involved and a personal commitment to being an active involved part of the learning community; they spoke of getting involved because that is what is needed to be done. Respondents also mention professional responsibility and that it was the responsibility of teacher librarians to step up and take on this role not only because of their knowledge and skills, but also a personal desire or self-motivation to be involved. Zinn (1997) defines this as an "initiator," a teacher who recognizes that leadership is needed in a situation and is willing to step up and take on additional responsibility.

The commitment to continual growth is a prominent enabler in facilitating teacher librarians' involvement in technology integration leadership practices. These efforts are designated differently from "professional development opportunities" which represent formal professional development leadership opportunities through institutional structures. Aligning with the literature, this research conveys the importance of professional growth in leadership involvement, but respondents in both studies frequently note informal professional growth activities that enabled them to be involved in technology integration leadership practices. Respondents comment on their efforts and commitment to continual learning and staying current, including personal informal self-initiated efforts such as reading journals, attending conferences, reading web pages, joining listervs, creating a PLN (Personal Learning Networks) through social media, and attending webinars. This is consistent with Miller's (as cited in Massey, 2009) findings that professional development gained either from attending conferences or from consulting with colleagues, positively influenced technology integration. When asked how they prefer to learn to use technology tools and applications, teacher librarians in the 2008 research by Hughes-Hassell and Hanson-Baldauf also chose methods that indicated self-motivation and that they were willing to learn technology on their own time to develop their expertise. Teacher leaders are consummate learners and research suggests that a sense of inquiry and love of learning enables teachers to assume leadership responsibilities (Katzenmeyer \& Moller, 2009; Zinn, 1997). Technology is constantly changing and it is essential that teacher librarians to stay up to date through continuing their 
professional learning in order to advance and hone the skills and knowledge that are mandatory to lead in technology integration efforts.

\section{Implications}

The initial study served as the initial identification of enablers and barriers that teacher librarians experience in enacting a technology integration leadership role. This replication of the research with a larger random sample contributes to the validity and the reliability of the findings. While the overall goal was not generalizability, there are implications of interest to the school library profession as a whole. The findings from this study have implications for the teacher librarian research and literature, including an adapted framework; for teacher librarian preparation programs; and for the practice of teacher librarianship.

The implication for the research and literature of teacher librarianship and teacher leadership is that this study fills a gap in the existing teacher librarian research and contributes to the literature regarding teacher librarians as leaders in technology integration. Currently there is very little research that examines leadership roles of teacher librarians and no research that examines teacher librarian leadership practices in technology integration within a teacher leader framework. While there is limited research on teacher librarians' role in technology integration and separate research on the leadership role, there is little empirical research that combines the two areas to examine teacher librarians as technology integration leaders.

Additionally the replication research allowed for reusing the survey and utilizing the adapted framework created as a result of the initial study, contributing to instrument reliability and validity for both the survey and the framework.

The ambiguity surrounding the technology integration leadership role has led to teacher librarians who are ill prepared to enact this vital role. The identification of the enablers and barriers that teacher librarians experience enacting a leadership role is valuable information for school library preparation educators. Future teacher librarians can be taught how to identify enablers and develop strategies to use them to their advantage. The findings from this research can be useful for planning curriculum to better prepare teacher librarians to assume an active leadership role. Teacher librarian preparation programs need to include competencies that support the concept of teacher leadership and teach teacher librarians leadership skills such as effective communication, relationship building, problem solving, conflict resolution, time management, and other skills that will prepare them to assume leadership roles.

The primary implication of this research is the identification of the enablers and barriers that can facilitate and constrain teacher librarians' involvement in technology integration leadership. The ambiguity surrounding the technology integration leadership role has led to teacher librarians who are uncertain how to perform this role in practice. This research informs practice by providing support for teacher librarians in searching out those factors that will enable enactment and in identifying the barriers that must be overcome in order to achieve this vital role in practice. These findings are useful to furthering the understanding of this role for practicing teacher librarians who seek to enact or expand their leadership role in technology integration.

\section{References}

Albertson, D., \& Johnston, M. P. (2015). Science teachers and interactive video retrieval. 
Electronic Library.

Alliance for Excellent Education. (2011). Digital learning and technology: Federal policy recommendations to seize the opportunity —and promising practices that inspire them. Washington, DC. Retrieved from http://www.all4ed.org/files/DigitalLearning.pdf

Alliance for Excellent Education. (2012). The digital learning imperative: How technology and teaching meet today's education challenges. Washington, DC. www.all4ed.org/files/DigitalLearninglmperative.pdf

American Association of School Librarians (AASL). (2009). Empowering learners: Guidelines for school library media programs. Chicago: American Library Association.

American Association of School Librarians (AASL) \& Association for Educational Communications and Technology (AECT). (1998). Information power: Building partnerships for learning. Chicago: American Library Association.

Anderson, R. E., \& Dexter, S. (2005). School technology leadership: An empirical investigation of prevalence and effect. Educational Administration Quarterly, 41(1), 49-82. doi:10.1177/0013161X04269517

Babbie, E. (2013). The practice of social research. (13th ed.). Belmont, CA: Wadsworth Thomson Learning.

Barth, R. S. (2001). Teacher leader. Phi Delta Kappan, 82(6), 443-449.

Branch-Mueller, J., \& de Groot, J. (2011). The power of web 2.0: Teacher-librarians become school technology leaders. School Libraries Worldwide, 17(2), 25-41.

Clark, R., \& Maynard, M. (1998). Using online technology for secondary analysis of survey research data - Act globally, think locally. Social Science Computer Review, 16(1), 58-71. doi: $10.1177 / 089443939801600108$

Common Sense Media. (2013). Teaching with technology: The promise and reality of the U.S. digital classroom. Retrieved from https://www.graphite.org/blog/teaching-withtechnology-the-promise-and-reality-of-the-us-digital-classroom

Darling-Hammond, L., Zielezinski, M. B., \& Goldman, S. (2014). Using technology to support at-risk students' learning. Washington DC: Alliance for Excellent Education and Stanford Center for Opportunity Policy in Education.

Diekema, A. R. \& Olsen, M. W. (2012). The notion of relevance in teacher information behavior. Proceedings of the American Society for Information Science and Technology, 49(1), 1-9.

Digedu (2014) Technology use in the classroom: Benefits \& barriers. Retrieved from http://digedu.com/wp- content/uploads/2014/04/Benefits-Barriers-Report.pdf 
Dillman, D. A., Smyth, J. D., \& Christian, L. M. (2009). Internet, mail, and mixed-mode surveys: Tailored design method (3rd ed.). Hoboken, NJ: Wiley \& Sons.

DiScala, J., Moses, A., Weeks, A. C. (2015). Take me to your leader: The (invisible) school district library supervisor. School Library Monthly, 31(5), 29-31.

Duffey, D. \& Fox, C. (2012). National educational technology trends 2012: State leadership empowers educators, transforms teaching and learning. Washington, DC: State Educational Technology Directors Association (SETDA).

Duke, T. S., \& Ward, J. D. (2009). Preparing information literate teachers: A metasynthesis. Library \& Information Science Research, 31, 247-256.

Ertmer, P. A. (2005). Teacher pedagogical beliefs: The final frontier in our quest for technology integration? Educational Technology Research and Development, 53(4), 41-56. doi:10.1007/BF02504683

Everhart, N., \& Dresang, E. T. (2006, January). School library media specialists for the 21st century: Leaders in education make a difference. Paper presented at the Association for Library and Information Science Education (ALISE) National Conference, San Antonio, TX.

Everhart, N., Mardis, M., \& Johnston, M. P. (2012). National Board Certified school librarians' leadership in technology integration: Results of a national survey. School Library Media Research, 14. Retrieved from http://ala.org/aasl/aas/pubsandjournals/s/mrb/

Hanson-Baldauf, D., \& Hughes-Hassell, S. (2009). The information and communication technology competencies of students enrolled in school library media certification programs. Library and Information Science Research, 31(1), 3-11. doi:10.1016/j.lisr.2008.03.003

Hew, K. F., \& Brush, T. (2007). Integrating technology into K-12 teaching and learning: Current knowledge gaps and recommendations for future research. Educational Technology Research and Development, 55(3), 223-252. doi:10.1007/s11423-0069022-5

Hughes-Hassell, S., \& Hanson-Baldauf, D. (2008). Information and communication technology use by North Carolina school library media specialists: Perceived competencies and barriers. School Library Media Research, 11. Retrieved from http://www.ala.org/aasl/sites/ala.org.aasl/files/content/aas/pubsandjournals/slr/vol1 1/SLMR InformationCommunication V11.pdf

International Society for Technology in Education (ISTE). (2000). National educational technology standards for students: Connecting curriculum and technology. Retrieved from http://www.iste.org/standards 
Johnston, M. P. (2015). Blurred lines: The school librarian and the technology specialist. The school librarian perspective. Tech Trends.

Johnston, M. P. (2012). Connecting teacher librarians for technology integration leadership. School Libraries Worldwide, 18(1), 18-33.

Johnston, M. P. (2012). School librarians as technology integration leaders: Enablers and barriers to leadership enactment. School Library Research, 15(1). Retrieved from www.ala.org/aasl/slr

Johnston, M. P. (2011). School librarians at technology integration leaders: Enablers and barriers to leadership enactment. (Doctoral Dissertation). Retrieved from Dissertation Abstracts International. (3483677).

Katzenmeyer, M., \& Moller, G. (2009). Awakening the sleeping giant: Helping teachers develop as leaders (3rd ed.). Thousand Oaks, CA: Corwin.

Mardis, M. A. (2009). Classroom information needs: Search analysis from a digital library for educators. D- Lib, 15(1/2). Retrieved from http://www.dlib.org/

Mardis, M. A., ElBasri, T. E., Norton, S. K., \& Newsum, J. (2012). The new digital lives of teachers: A research synthesis and trends to watch. School Libraries Worldwide, 18(1), 70-86.

Massey, S. A. (2009). Digital libraries in schools: The best practices of National Board Certified library media specialists. (Doctoral dissertation). Retrieved from Dissertation Abstracts International. (3359753).

Neuendorf, K. (2002). The content analysis guidebook. Thousand Oaks, CA: Sage.

Office of Educational Technology. (2010). Transforming American education: Learning powered by technology. National Educational Technology Plan (NETP) 2010. Washington, DC: U.S. Department of Education.

Partnerships Advancing Library Media (PALM) Center, Florida State University (2009). School library media specialist and technology integration survey. Unpublished instrument.

Project Tomorrow. (2012). Speak up 2011: Mapping a personalized learning journey-K-12 students and parents connect the dots with digital learning. Irvine, CA. http://www.tomorrow.org/speakup/pdfs/SU11 PersonalizedLearning Students.pdf

Project Tomorrow. (2014). The new digital playbook: Understanding the spectrum of students' activities and aspirations. Irvine, CA: Project Tomorrow. Retrieved from http://www.tomorrow.org/speakup/SU13DigitalLearningPlaybook StudentReport.ht $\underline{\mathrm{ml}}$

Robertson, M. O. (2008). Distributing leadership to teachers through a district level math 
council. (Doctoral Dissertation). Retrieved from Dissertation Abstracts International. (3296859).

Scholastic. (2008). School libraries work! Retrieved from http://www2.scholastic.com/content/collateral resources/pdf/s/s/w3 2008.pdf

Shannon, D. M. (2002). The education and competencies of school library media specialists: A review of the literature. School Library Media Research, 5. Retrieved from http://www.ala.org/ala/mgrps/divs/aasl/aas/pubsandjournals/s/mrb/schoollibrary.cf $\underline{\mathrm{m}}$

Spillane, J. P. (2006). Distributed leadership (1st ed.). San Francisco, CA: Jossey-Bass.

Stewart, D. W., \& Kamins, M. A. (1993). Secondary research: Information sources and methods. Newbury Park, CA: Sage.

U.S. Department of Education. 2013. Expanding evidence approaches for learning in a digital world. Washington, DC: Office of Educational Technology. Retrieved from http://tech.ed.gov/files/2013/02/Expanding-Evidence-Approaches.pdf

Todd, R. J. (2008). Youth and their virtual networked worlds: Research findings and implications for school libraries. School Libraries Worldwide, 14(2), 19-34. Retrieved from http://www.iasl-online.org/pubs/slw/index.htm

Vaughan, L. (2001). Statistical methods for the information professional: A practical, painless approach to understanding, using, and interpreting statistics. Medford, $\mathrm{NJ}$ : Information Today.

Wolf, M. A., Jones, R., \& Gilbert, D. (2014). Leading beyond the library. Washington, DC: Alliance for Excellent Education.

York-Barr, J., \& Duke, K. (2004). What do we know about teacher leadership? Findings from two decades of scholarship. Review of Educational Research, 74(3), 255-316. doi:10.3102/00346543074003255

Zinn, L. P. (1997). Supports and barriers to teacher leadership: Reports of teacher leaders. (Doctoral dissertation). Retrieved from Dissertation Abstracts International. (304369244)

Zmuda, A., \& Harada, V. H. (2008). Librarians as learning specialists: Moving from the margins to the mainstream of school leadership. Teacher Librarian, 36, 15-20.

\section{Biographical Note}

Melissa P. Johnston is an Assistant Professor at The University of Alabama in the School of Library and Information Studies, where she coordinates and teaches graduate courses in the school library media certification program. Johnston worked as a school librarian for 13 years in Georgia before completing her PhD at Florida State University's School of Information. Johnston received the IASL Ken Haycock Leadership Award in 2013 and the IASL Takeshi 
Murofushi Research Award in 2011 to investigate international school librarian practices. In 2014 Johnston was the co-recipient of the Association for Educational Communications and Technology Cross-Cultural Research Award. Johnston's research and publications focus on school librarians as leaders, the school librarian's role in technology integration, and school librarianship on a global level. 